\title{
A Global Review of Farmers' Perceptions of Agricultural Risks and Risk Management Strategies
}

\author{
Thi Tam Duong ${ }^{1, *(\mathbb{D})}$, Tom Brewer ${ }^{2}$, Jo Luck ${ }^{3}$ and Kerstin Zander ${ }^{1}$ \\ 1 Northern Institute, Charles Darwin University, Darwin, NT 0909, Australia; kerstin.zander@cdu.edu.au \\ 2 Australian National Centre for Ocean Resources and Security (ANCORS), University of Wollongong, \\ Wollongong, NSW 2522, Australia; tomdbrewer@gmail.com \\ 3 Plant Biosecurity Research Initiative, Horticulture Innovation, 606 St Kilda Road, \\ Melbourne, VIC 3004, Australia; jo.luck@horticulture.com.au \\ * Correspondence: ethitam.duong@cdu.edu.au; Tel.: +61-8-8946-6131
}

Received: 12 December 2018; Accepted: 28 December 2018; Published: 4 January 2019

\begin{abstract}
Farmers around the world face and manage a wide range of enterprise-related risks. These risks are increasing due to a range of factors including globalisation, increased trade in agricultural products, and climate change, jeopardising agricultural enterprises and forcing farmers to adjust their production and management strategies. Here we present results of a systematic literature review, following PRISMA protocol, of farmers' perceptions of, and responses to, agricultural risks. Using data reduction method (factor analysis) and descriptive statistics, we analysed 197 studies and found that weather-related risk (55\%), biosecurity threats (48\%), and human risk (35\%) are the significant risks perceived by farmers for their agricultural enterprises. Diversification of crop and animal production (28\%) and pests and diseases monitoring and prevention $(20 \%)$ were the preferred agricultural risk management strategies employed by farmers. Few studies have investigated socio-economic factors that explain risk perceptions $(18 \%)$ or factors that influence how farmers manage agricultural risks $(11 \%)$. The main barriers to successfully managing agricultural risks were limited access to information and formal low-interest loan systems, especially in developing countries. We identified a mismatch between perceived risk sources and risk management strategies, highlighting a need to improve understanding of why particular management responses are employed to address the various risks. This review suggests areas for future research to improve understanding of the perceptions of risks held by farmers, and to support efforts to manage and reduce these risks.
\end{abstract}

Keywords: review; risk sources; factor analysis; risk management strategies; perceptions

\section{Introduction}

Agricultural enterprise has always been at risk from factors such as pest and disease attack, uncontrollable weather events and market variability [1-3]. Many risks are now being exacerbated by global environmental, social, and economic change, including continued human population growth, limited arable land, land degradation, and climate change [4-6]. Agricultural risks come from different sources and are experienced to differing degrees across different geographic and political scales. Sources of agricultural risks have previously been classified into price or market risk (output and input price fluctuation, market shocks), financial risk (loans and credits), production risk (weather-related risk, pests and diseases (biosecurity threats), technology change, yields), institutional risk (regulations, legal, environment and tax policy), and human resource risk (physical and mental health) $[7,8]$.

Farmers' management response to risks is influenced by their perceptions of the risk concerned [9]. Based on how they perceive risks, farmers implement a wide range of strategies to limit the impacts of 
agricultural risks [1,10-12]. Farmers employ strategies including informal mechanisms at the farm level (crop and animal diversification and advanced technology applications) to formal mechanisms like insurance and contracting [13].

With different socio-economic backgrounds (age, education, culture, religion, farming practice, income, peer pressure, and community values) farmers' have different risk perceptions, resulting in different economic behaviours and decision-making [14,15], including response to risks. Farmer-level choices to adopt management strategies and successfully manage risks have been shown to be limited by many factors, including the absence of transparent information, limited institutional support, and lack of capital [16,17]. To enable improved institutional support relating to risk management, it is, therefore, essential to understand farmers' risk perceptions, the socio-economic factors that influence risk perceptions and likely response to risks, and the barriers to implementing management strategies [5,18-21]. For example, in recent years, research has investigated how farmers perceive agricultural risks, and how farmers respond to particular perceived risks [2,22], factors affecting farmers' perception and strategies [23-25], and barriers to risk management [26]. Those studies primarily focus on individual cases on crops and animals, ranging from developing countries [27] to developed countries [5] spanning Asia [28], Africa [29], and Europe [30].

While the existing literature has begun to tie these various concepts together in case studies, there has not, to date, been a systematic review of how these concepts are related, in the context of agricultural risks. The aims of this study are, therefore, to review the existing literature to identify (1) the major sources of agricultural risks perceived by farmers, (2) common risk management strategies employed by farmers, (3) linkages between risk sources and risk management strategies, (4) socio-economic factors that affect farmers' perceptions and management strategies, and (5) the barriers to the management of agricultural risks.

\section{Materials and Methods}

To address the research aims a systematic review of literature published in international peer-reviewed journals was undertaken using the Preferred Reporting Items for Systematic Reviews and Meta-Analyses (PRISMA) protocol (see Moher et al. [31]).

\subsection{Eligibility Criteria}

Articles were included in this review, if they discussed (i) risk sources perceived by farmers or management strategies, (ii) farmers' management strategies, (iii) socio-economic factors affecting risk sources perceived by farmers or management strategies, (iv) any general barriers farmers perceived when operating farming enterprises, and (v) were written in English and peer-reviewed. Quantitative as well as qualitative studies were included, and no matter of the source of the data. Studies relating to farmers but not related to their perceptions towards agricultural risk sources, their management strategies, or factors affecting their perceptions were excluded (such as if they focused on agricultural conservation, sustainable agriculture, energy, or biomass). With the aim to achieve homogeneous data, it was assumed that farmers worked at a particular farm, so it was decided not to include the keywords herders and pastoralists in the search strategies.

\subsection{Search Strategy}

The keywords (agricultur* OR farm*) AND (perception OR perceive*) AND risk* were used to search titles, abstracts and keywords in Scopus to obtain articles published prior to 9 December 2017. It was decided not to set a start date so that search results could be able to capture any available studies prior to 9 December 2017. Asterisks were used to capture possible derivations of words. After filtering for English and peer-reviewed items, 2506 articles were obtained. The search was also conducted on Web of Science and Google Scholar and found an additional 124 and 66 articles, respectively. Of all 2696 articles, 94 duplicates were removed, leaving 2602 articles for title and abstract screening to confirm they fulfilled the inclusion criteria. The titles of each study were then screened using the keywords (risk 
perception* OR risk management OR risk sources OR perceived risks) AND (animal OR crop) OR (farmers OR growers OR producers OR agriculture) resulting in the exclusion of 2081 articles. This process was conducted through a period of three months by the lead author. The remaining 521 full-text articles were then screened, and 324 articles were excluded as they did not meet the eligibility criteria. Studies discussing farmers' perceptions and management of biodiversity and natural resources, forestry and aquaculture were not included for further analysis. A remaining 197 articles were eligible for the review; 81 discussing farmers' perceptions on agricultural risk sources; 23 investigating farmers' risk management strategies, and 93 focusing on both those topics (Figure 1 and Table S1).

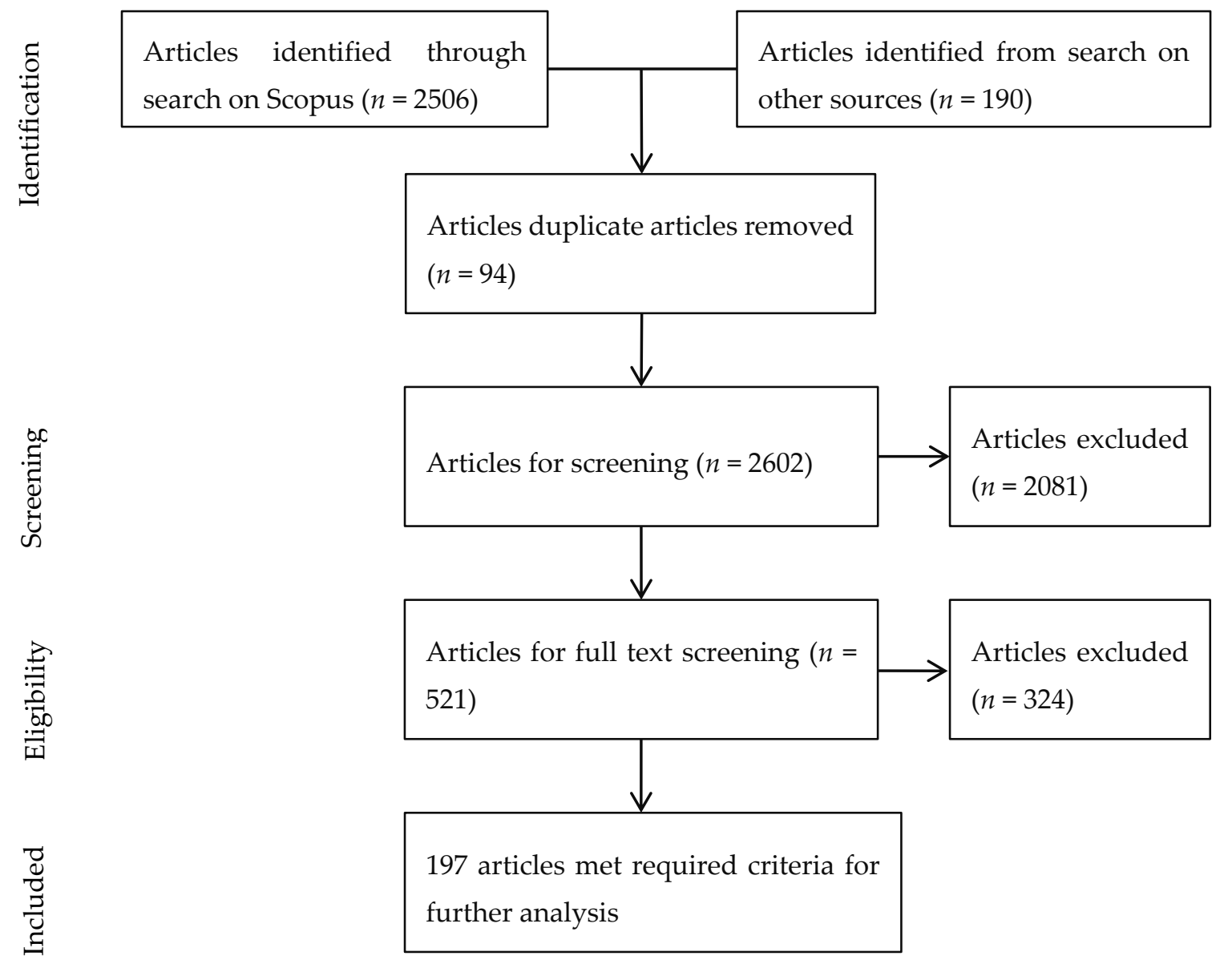

Figure 1. PRISMA review.

\subsection{Categorisation}

The reviewed literature was categorised into seven categories of risk. Five of the categories are widely used: output price and market risk, financial risk, production risk, institutional risk, and human risk [7,8,32,33]. Market risk includes input and output price fluctuation and any market shocks. Financial risk consists of loans, interest rates, and relates to the financing of farms. Production risk mainly originates from unpredictable weather events, pest and disease attack (biosecurity), yield loss, and technological risk. Institutional risk comprises unfavourable government-enforced changes in policy, rules, tax, and regulations. Human risk is associated with the farm owners or farmers, in the event of death and sickness, which may result in the loss of profit or the sustainability of the farming business.

Production risk is the significant risk source [34], as agricultural production and food security have been increasingly influenced by climate change and pests and diseases [35-38]. Thus, further distinctions were made by breaking down production risk into a sixth category, weather and climate change risk, which is often part of weather-related risk, and a seventh category, biosecurity threats (such 
as pest and disease outbreak, invasive species). Following the categorisations of the World Bank [13] and Hay [39], technological risk was a main risk within production risk and thus could be categorised as one group of risk. There were, therefore, a total of seven categories of risk sources.

\subsection{Data Analysis}

Firstly, to explore the nature and trend of risk sources and risk management strategies, the data were analysed using descriptive statistics and Factor Analysis with Kaiser Mayer Olkin normalisation and Varimax rotation [40]. Statistical tests were performed with SPSS (Version 25, IBM, New York, NY, USA). Secondly, to uncover linkages between particular risks and risk management strategies, factor analysis was used along with Spearman's Rank Correlation analysis. Thirdly, the factors affecting farmers' perceptions of risk sources, risk management strategies, and barriers to managing agricultural risks were summarised based on the aggregated data from descriptive statistics.

\section{Results}

\subsection{Snapshot of Selected Studies}

The number of studies on farmers' perceptions of agricultural risks and their management strategies has increased notably over time, particularly from 2010, onwards (Figure 2).

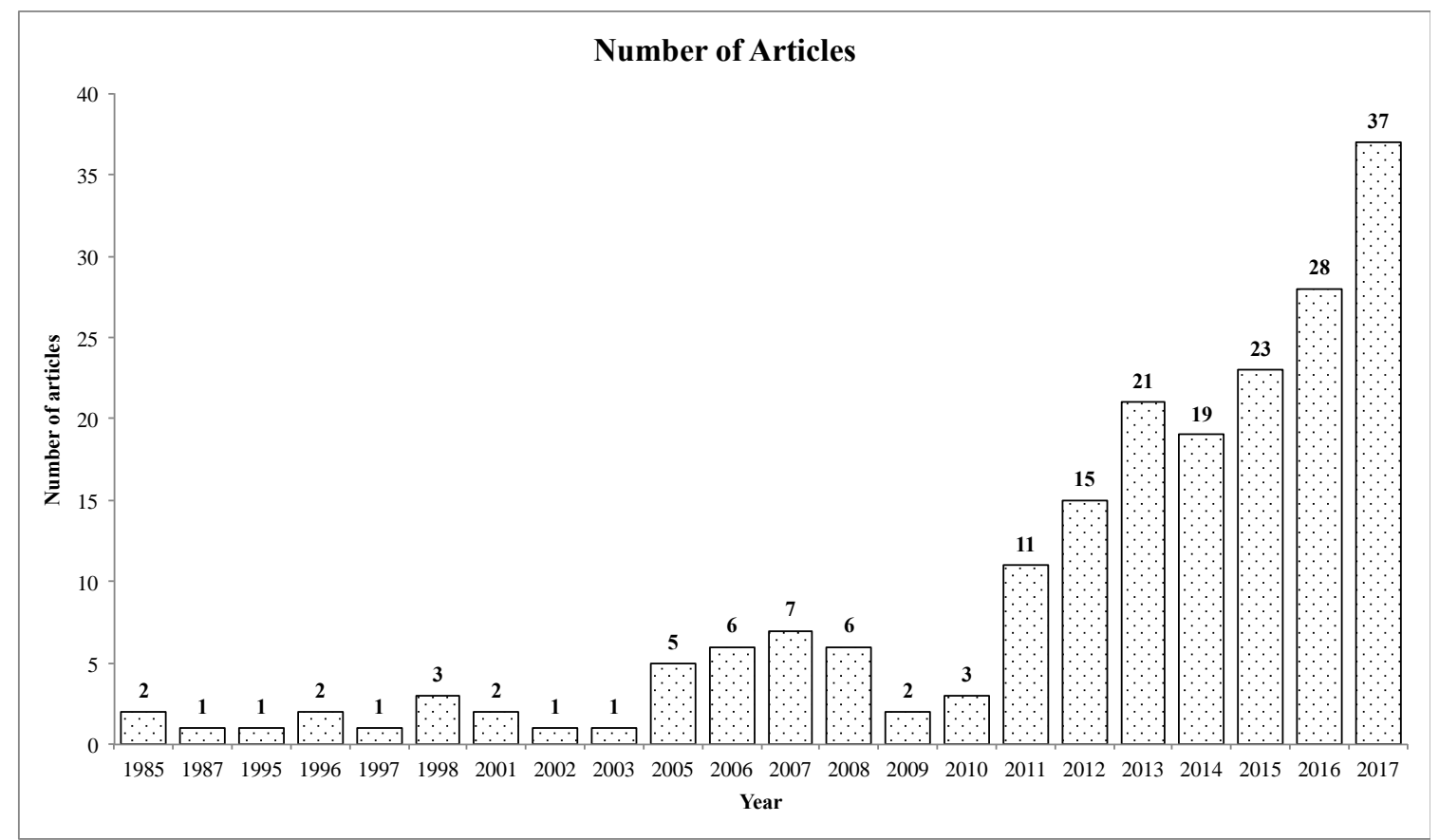

Figure 2. Number of articles on farmers' perception of risk sources and risk management strategies over the period 1985-2017s $(n=197)$. Numbers above bars are the number of articles.

Studies were predominantly conducted in Asia (29\%), followed by America (25\%), Europe (22\%), Africa (19.5\%), and Oceania (4.5\%). More than half of the studies (54\%) explored agricultural risks in the crop sector, while there were $27 \%$ in the animal sector, and $19 \%$ in mixed production sectors (both crop and animal). Based on the classification of the United Nations (2014), 57\% of the studies were conducted in developing countries. Surprisingly, of the obtained 197 studies, there was no study conducted across both developing and developed countries. Of the studies, $41 \%$ ( 81 studies) only dealt with farmers' agricultural risk perceptions, $12 \%$ (23 studies) only with risk management, and $43 \%$ (93 studies) focused on both perceptions of agricultural risks and management responses to agricultural risks. Findings showed that all studies in this review presented results from analysing primary data. 


\subsection{Agricultural Risk Perceived by Farmers}

In general, more than half $(55 \%)$ of the studies reported that farmers perceived weather and climate change as the main risk to their farm enterprises, followed by biosecurity threats (48\%), human risk ( $35 \%)$, and market risk (27\%), while technology was least frequently mentioned (Figure 3). Weather risk, human risk, and biosecurity threats were the most frequently cited risks by the farmers in the crop sector. In the animal sector, biosecurity threats, weather risk, and human risk are the most frequently cited. In the mixed production sector (crop and animal), the most cited risks in studies were weather risk, biosecurity threats, and market risk (Figure 4).

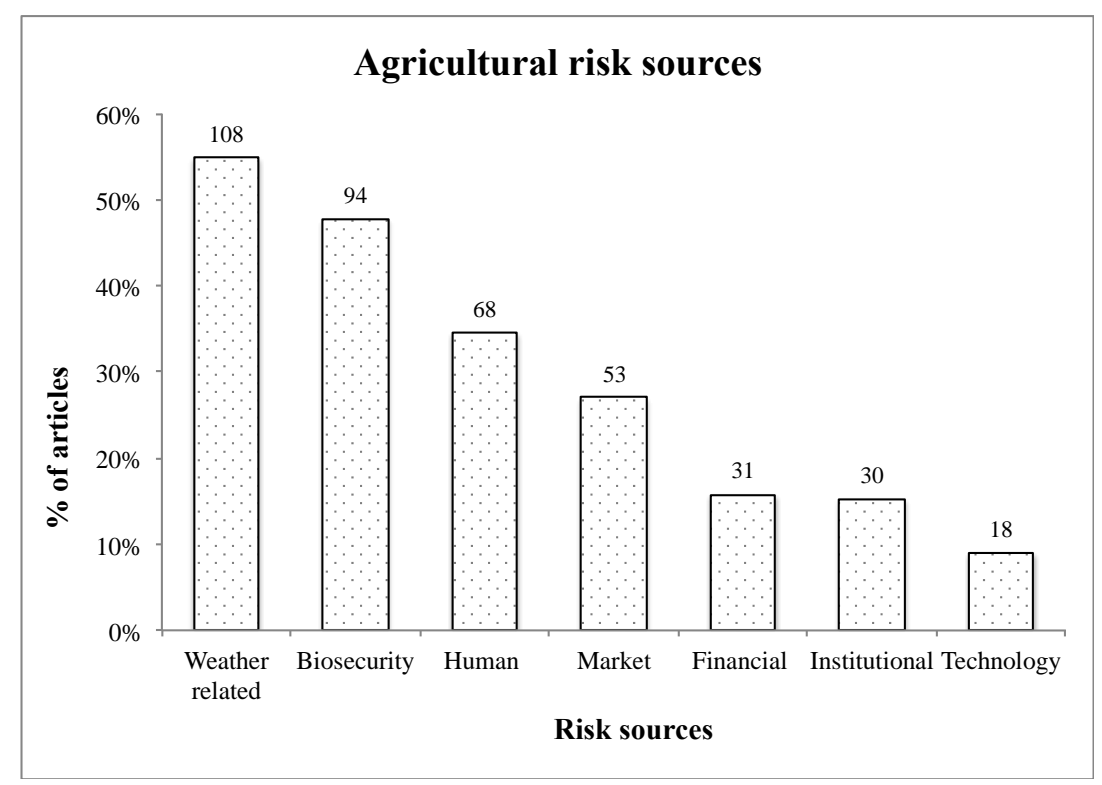

Figure 3. Distribution of agricultural risk sources as identified in the review $(n=174)$. Numbers above bars are the number of articles studying risks.

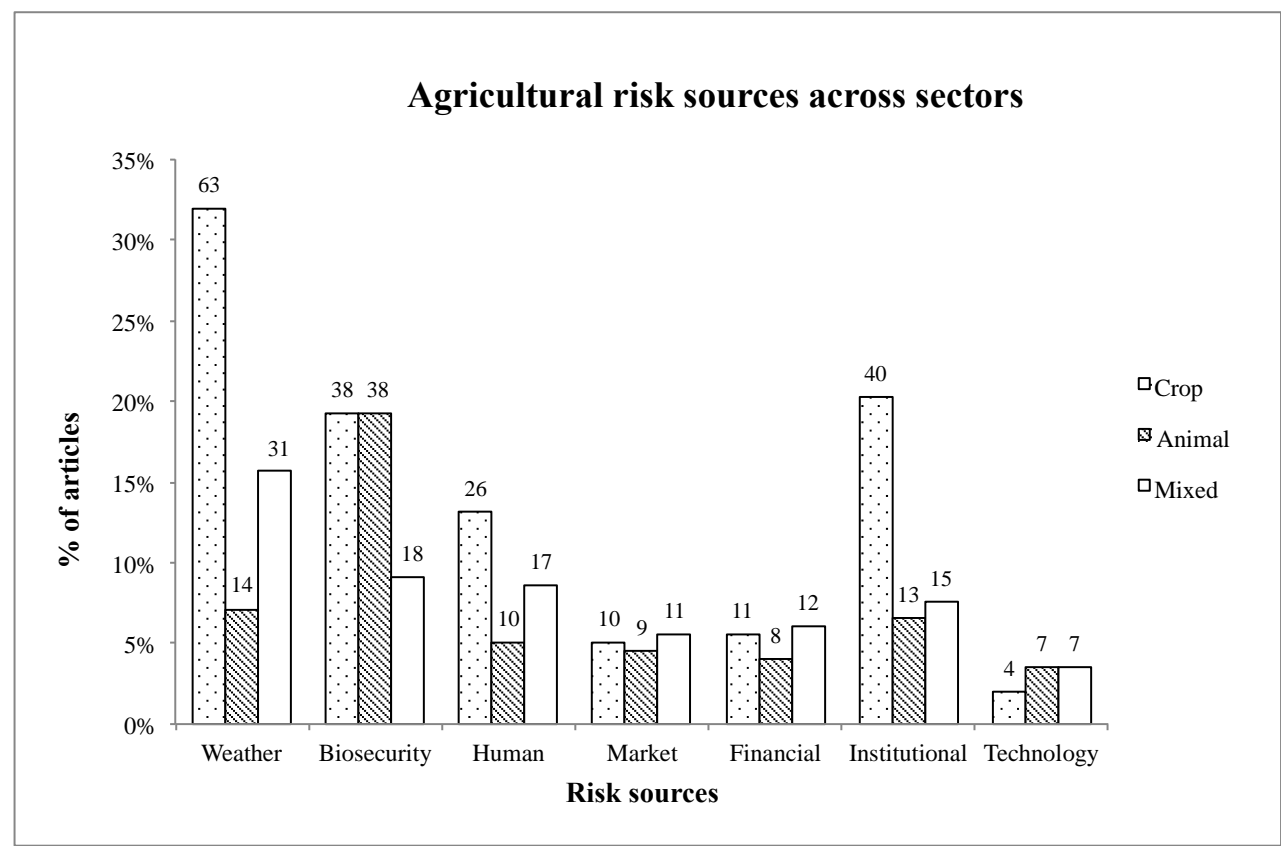

Figure 4. Distribution of agricultural risk sources across three sectors $(n=174)$. Numbers above bars are the number of articles discussing risk sources across sectors. 
There were notable differences in farmers' perceptions of risk source between studies in developing countries and developed countries. Weather-related risk, biosecurity threats, and human risk were mostly cited in developing countries while in developed countries biosecurity threats was the most cited, followed by weather-related risk and human risk (Table 1).

Table 1. Number of studies citing risk sources perceived by farmers in developed and developing countries $(n=197)$.

\begin{tabular}{clclc}
\hline Countries & \multicolumn{2}{c}{ Developing $\left(\boldsymbol{n}_{\mathbf{1}} \mathbf{= 1 1 2}\right)$} & \multicolumn{2}{c}{ Developed $\left(\boldsymbol{n}_{\mathbf{2}}=\mathbf{8 5}\right)$} \\
\hline Weather related & $n=75$ & $67 \%$ & $n=33$ & $39 \%$ \\
Biosecurity & $n=48$ & $43 \%$ & $n=46$ & $54 \%$ \\
Human & $n=41$ & $37 \%$ & $n=27$ & $32 \%$ \\
Market & $n=30$ & $27 \%$ & $n=23$ & $27 \%$ \\
Financial & $n=16$ & $14 \%$ & $n=15$ & $18 \%$ \\
Institutional & $n=10$ & $9 \%$ & $n=20$ & $24 \%$ \\
Technology & $n=8$ & $7 \%$ & $n=10$ & $12 \%$ \\
\hline
\end{tabular}

Factor analysis of perceived risks explained $77.52 \%$ of the total variance across three components (Table 2). The factor model had a Kaiser Mayer Olkin measure of 0.780 and a Bartlett's Test of Sphericity of $(p<0.001)$. The first component, labelled direct risks to production, was the most strongly comprised of "human risk", "market risk", "financial risk", "institutional risk" and "technology risk". The second and third components were comprised of weather and biosecurity, respectively.

Table 2. Results of factor analysis on farmer's perceptions of agricultural risk sources $(n=174)$ (Varimax rotated, Coefficient values $\geq 0.5$ in bold).

\begin{tabular}{cccc}
\hline Risk Sources & Direct Risks to Production & Weather & Biosecurity \\
\hline Human & $\mathbf{0 . 6 5 5}$ & -0.489 & -0.389 \\
Market & $\mathbf{0 . 7 7 5}$ & 0.135 & 0.225 \\
Financial & $\mathbf{0 . 8 2 3}$ & 0.092 & 0.185 \\
Institutional & $\mathbf{0 . 8 1 2}$ & 0.119 & 0.168 \\
Technology & $\mathbf{0 . 8 2 6}$ & 0.016 & 0.056 \\
Weather & 0.212 & $\mathbf{0 . 9 2 8}$ & -0.104 \\
Biosecurity & 0.282 & -0.087 & $\mathbf{0 . 9 0 9}$ \\
Factor interpretation (\% variance & $47.07 \%$ & $16.46 \%$ & $13.98 \%$ \\
explained) & & & \\
\hline
\end{tabular}

\subsection{Risk Management Strategies Adopted by Farmers}

Twelve risk management strategies were constructed based on the most relevant strategies discussed in the reviewed studies. More than a quarter of the studies $(28 \%)$ found that farmers considered "crop and animal diversification" to be an effective risk management strategy (Table 3). "Pests and diseases monitoring and prevention" was adopted by farmers in 40 studies. "Off-farm work" (14\%) and obtaining "farm insurance" $(13 \%)$ were the third and fourth most frequently stated management strategies. "Cooperation with other farmers", "extension services" and "training and education" were less frequently stated (Table 3 ). 
Table 3. Frequencies of risk management strategies taken by farmers across reviewed literature $(n=116)$. Note, many articles described more than one risk strategy.

\begin{tabular}{ccc}
\hline Risk Management Strategies & Number & \% \\
\hline Crop and animal diversification & 56 & 28 \\
Pests and diseases monitoring and prevention & 40 & 20 \\
Off-farm work & 27 & 14 \\
Farm insurance & 25 & 13 \\
Off-farm investment & 20 & 10 \\
Debt reduction & 19 & 10 \\
New technology adoption & 13 & 7 \\
Produce at the lowest costs & 11 & 6 \\
Extension services & 9 & 5 \\
Cooperation with other farmers & 8 & 4 \\
Update with government & 8 & 4 \\
Training and education & 2 & 1 \\
\hline
\end{tabular}

Factor analysis of management strategies resulted in three components (factors) explaining $58.87 \%$ of the total variance (Table 4). The factor model had a Kaiser Mayer Olkin measure of 0.784 , and the Bartlett's Test of Sphericity was significant $(p<0.001)$. In the first component, the risk management strategies with the highest loadings were "crop and animal diversification", "pests and diseases monitoring and prevention", "off-farm work", "farm insurance", "off-farm investment", "debt reduction", "produce at the lowest costs", and "cooperation with other farmers". The first component was labelled as on-farm and financial strategies. The second component, knowledge support, had high loadings for three variables "extension services", "update with government", and "training and education". The last component, productivity solutions" included "crop and animal diversification" and "new technology adoption".

Table 4. Results of factor analysis on management strategies used by farmers $(n=116)$ (Varimax rotated; Coefficient values $\geq 0.45$ in bold).

\begin{tabular}{cccc}
\hline Risk Management Strategies & $\begin{array}{c}\text { On-Farm and Financial } \\
\text { Strategies }\end{array}$ & Knowledge Support & Productivity Solutions \\
\hline Pests/diseases monitoring and prevention & $\mathbf{0 . 4 6 3}$ & 0.178 & -0.523 \\
Off-farm work & $\mathbf{0 . 5 9 1}$ & 0.238 & 0.245 \\
Farm insurance & $\mathbf{0 . 7 2 9}$ & 0.143 & 0.137 \\
Off-farm investment & $\mathbf{0 . 7 8 6}$ & 0.214 & 0.016 \\
Debt reduction & $\mathbf{0 . 8 0 8}$ & 0.028 & 0.082 \\
Produce at the lowest costs & $\mathbf{0 . 7 3 0}$ & -0.019 & -0.161 \\
Cooperation with other farmers & $\mathbf{0 . 5 9 3}$ & 0.007 & 0.001 \\
Crop and animal diversification & $\mathbf{0 . 6 1 5}$ & 0.096 & $\mathbf{0 . 5 1 9}$ \\
New technology adoption & 0.172 & 0.135 & $\mathbf{0 . 7 5 2}$ \\
Update with government & 0.105 & $\mathbf{0 . 7 4 7}$ & 0.166 \\
Training and education & -0.089 & $\mathbf{0 . 8 8 0}$ & 0.061 \\
Extension services & 0.365 & $\mathbf{0 . 6 7 2}$ & -0.186 \\
Factor interpretation (\% variance explained) & $31.75 \%$ & $16.40 \%$ & $10.72 \%$ \\
\hline
\end{tabular}

\subsection{The Linkage between Perceived Risk Sources and Management}

A factor analysis was performed on 93 studies (47\%) that explored both risk sources and risk management strategies, resulting in six components explaining $71.32 \%$ of the total variance (Table 5). The factor model had a Kaiser Mayer Olkin measure of 0.793, and the Bartlett's Test of Sphericity was significant $(p<0.001)$. The first component, direct risks and financial strategies, included six risk sources: "human", "market", "input", "financial", "policy" and "technology"; with four risk management strategies: "farm insurance", "off-farm investment", "debt reduction", and "produce at the lowest costs". The second component, weather and strategies, comprised "weather" risk clustered with three management strategies "crop and animal diversification", "off-farm investment", and "off-farm work". The third component, knowledge support consisted of three risk management strategies "extension services", "update with government", and "training and education". The fourth component was 
named biosecurity and strategies as it comprised one risk source, "biosecurity", and one risk management strategy, "pests and diseases monitoring and prevention". The fifth and sixth components consist of two risk management strategies, "new technology adoption" and "cooperation with other farmers", which were named technical solution and external relationship respectively.

Table 5. Results of factor analysis of studies combining risk perception and risk management $(n=93)$.

(Varimax rotated; Coefficient values $\geq 0.45$ in bold).

\begin{tabular}{|c|c|c|c|c|c|c|}
\hline $\begin{array}{l}\text { Risk Sources and Risk } \\
\text { Management Strategies }\end{array}$ & $\begin{array}{c}\text { Direct Risks and } \\
\text { Financial } \\
\text { Strategies }\end{array}$ & $\begin{array}{l}\text { Weather and } \\
\text { Strategies }\end{array}$ & $\begin{array}{l}\text { External } \\
\text { Support }\end{array}$ & $\begin{array}{l}\text { Biosecurity } \\
\text { and } \\
\text { Strategies }\end{array}$ & $\begin{array}{l}\text { Technical } \\
\text { Solution }\end{array}$ & $\begin{array}{c}\text { External } \\
\text { Relationship }\end{array}$ \\
\hline Human & 0.794 & -0.048 & 0.127 & 0.004 & 0.019 & -0.162 \\
\hline Financial & 0.778 & 0.135 & -0.025 & 0.180 & 0.142 & 0.211 \\
\hline Institutional & 0.747 & 0.246 & 0.113 & 0.234 & 0.071 & 0.075 \\
\hline Technology & 0.808 & 0.116 & 0.049 & 0.087 & -0.116 & 0.205 \\
\hline Farm insurance & 0.478 & 0.384 & 0.077 & 0.269 & 0.095 & 0.225 \\
\hline Off-farm investment & 0.596 & 0.461 & 0.191 & 0.149 & -0.114 & 0.162 \\
\hline Weather & -0.057 & 0.703 & 0.033 & -0.210 & 0.409 & 0.142 \\
\hline Crop and animal diversification & 0.341 & 0.471 & 0.011 & -0.088 & 0.433 & 0.264 \\
\hline Off-farm work & 0.281 & 0.770 & 0.145 & 0.240 & -0.117 & -0.107 \\
\hline Update with government & 0.290 & 0.100 & 0.777 & -0.127 & 0.106 & -0.126 \\
\hline New technology adoption & 0.033 & 0.023 & 0.109 & 0.055 & 0.862 & 0.060 \\
\hline Cooperation with other farmers & 0.241 & 0.117 & -0.008 & 0.029 & 0.138 & 0.818 \\
\hline $\begin{array}{c}\text { Factor interpretation (\% variance } \\
\text { explained) }\end{array}$ & $25.53 \%$ & $11.24 \%$ & $10.34 \%$ & $8.28 \%$ & $8.02 \%$ & $7.91 \%$ \\
\hline
\end{tabular}

Ten out of the 93 studies (11\%) concluded that there was a mismatch between farmers' perceptions of risks sources and their risk management strategies addressing the risks accordingly. This was confirmed by the results of Spearman's rank correlation coefficient. This test showed that some of the risk sources were not correlated with risk management strategies. Varying association between risk sources and risk management strategies were found (Table S2). There existed moderate agreements between "technology risk" and "produce at the lowest costs" ( $r^{2}=0.65 ; p$-value 0.01$)$; "institutional risk" and "off-farm investment" $\left(r^{2}=0.62 ; p\right.$-value 0.05), "debt reduction" $\left(r^{2}=0.62\right.$; $p$-value 0.01), "farm-insurance" $\left(r^{2}=0.55, p\right.$-value 0.01); "weather risk" and "crop and animal diversification" ( $r^{2}=-0.42, p$-value 0.01$)$; and "biosecurity threats" and "pests and diseases monitoring and prevention" $\left(r^{2}=0.31 ; p\right.$-value 0.01$)$.

\subsection{Socio-Economic Factors Affecting Farmers' Perceptions of Agricultural Risks}

Thirty-five studies (18\%) mentioned potential socio-economic factors determining farmers' perceptions of agricultural risks (Table S3). Factors included educational levels, farmers' age, gender, farm size, experience in farming, farm income, and farm location.

\subsection{Socio-Economic Factors Affecting Farmers' Choices of Risk Management Strategies}

Only 21 studies (11\%) investigated factors affecting farmers' adoption of risk management strategies. These studies, collectively, mentioned some factors including educational levels, farm size, experience in farming, farm location, farm ownership, gender, and annual farm income (Table S4).

\subsection{Barriers to the Management of Agricultural Risks}

Twenty-two out of 197 studies (11\%) explored barriers to the management of agricultural risks (Table S5). Lack of information helping farmers control agricultural risks was mentioned in 15 studies, mostly in developing countries. Poor access to formal, low risk, and regulated financing was found 
to hinder farmers' ability to manage their farming enterprises, as discussed in 10 studies. Limited institutional support and lack of market mechanisms (access and input supplies) were additional barriers encountered by farmers.

\section{Discussion}

\subsection{Perceptions of Risk Sources}

Our systematic literature review of research dealing with farmers' perceptions of agricultural risks and their management yielded 197 studies for detailed analysis. We categorised agricultural risks into seven types based on and combined with the various existing risk categorisations. Agricultural production heavily depends on demand and market price, and market risk was considered the most significant risk [8]. Surprisingly, in this review, market risk was more frequently mentioned than risk relating to weather and climate ( $55 \%$ of articles). Biosecurity threats were the second most frequently perceived risk across the reviewed studies, highlighting the emerging significance of biosecurity threats among all agricultural risks, which is corroborated by the observed increasing importance of biosecurity management [41].

Human risk was mentioned in 35\% of the studies, mostly in regard to human health (pesticide usage, some farmers' diseases). This was also expected as farming activities depend on physical labour, particularly in developing countries where humans are a pivotal asset to agricultural production [42]. Of the reviewed studies, $15 \%$ reported that farmers increasingly express concern about institutional risk, as changes to government policies can affect the viability and sustainability of farming enterprises [11,12].

The factor analysis identified three main clusters of risks, of which we classify direct risks to production as the first category. The second and third categories encompass weather risk and biosecurity threats. This demonstrates that farmers conceptualise risks associated with biosecurity and weather-related risks, such as climatic change, separately to other identified risk types. One reason why weather risk and biosecurity threats seem to be considered separately might be because farmers treated them as intrinsic features of farming production cycles rather than direct risks such as market risk and financial risk. Based on the intrinsic features of the two risks, if weather risk were grouped with biosecurity threats, it could improve future risk management because farmers with inadequate adaptive capacity are likely to be highly vulnerable to climate risks, especially smallholders or farmers in developing countries [43,44]. For instance, coupling pest and disease distribution predictions with climate predictions could reduce risks more efficiently than if both risks were managed separately.

The risk group of "human", "market", "institutional", "technology", and "financial" are direct risks to production and mostly occur as a consequence of farm-level decision-making and actions. Farmers need to gather information and make decisions themselves to manage those risks at the farm level, with decisions varying among farmers. Among the five risks in the group, market risk and institutional risk may be correlated because they are viewed as both expected and, as such, beyond the direct control of farmers. For example, any policy relating to agriculture such as environmental regulations, food safety, or business regulations will affect production [45], but the avenues by which farmers can influence such policy are at the best convoluted and insurmountable at worst.

\subsection{Risk Management Strategies}

Risk management strategies varied across studies. The most commonly selected strategies were to diversify production sectors to minimise risk [46,47], pursue off-farm work, or purchase insurance $[48,49]$. In most studies it was found that farmers were not likely to adopt new technologies although adopting innovative practices is pivotal to foster agricultural production sustainably [50] and efficiently [51].

The factor analysis identified that "training and education" and "extension services" correlated with "update with government", which may indicate that training and extension services from relevant 
government bodies are generally well received by farmers. Farmers' participation in training has been shown to increase net income and higher yield [52]. Some training programs which were initiated by the government delivered a positive outcome for farmers [53]. The other clusters of risk management strategies are "productivity strategies" and "financial strategies".

\subsection{The Linkage between Risk Sources and Risk Management Strategies}

Risk perception can affect economic behaviour, and thus the decision to adopt a specific risk management strategy [54]. Many studies have demonstrated that risk perception and risk management strategies are understood and analysed on a case-by-case basis [55-58], so it is essential to explore potential mismatch between risk sources and management and the reasons why farmers select particular strategies over others. The mismatch between perceived risks and risk management strategies was identified by the authors of $11 \%$ of 197 studies (10 studies).

The factor analysis found some correlations and patterns between risk sources and risk management strategies. Firstly, the "direct risks and financial incentives" group includes the risks (market, financial, human, institutional, and technology), and those risks are mainly matched with financial strategies (farm insurance, debt reduction, produce at the lowest cost). On the one hand, those strategies were seen as effective in tackling the volatility of output and input prices, and unfavourable changes in the financial market, but were not relevant in tackling "human risk." Secondly, facing weather risk, farmers have a range of strategies to diversify their income (off-farm investment, off-farm work, crop and animal diversification), while when facing biosecurity threats, they tend to rely on only "pests and diseases monitoring and prevention". Maybe the weather has always been an issue, and farmers learned constantly adapt to changes in weather and climate, but biosecurity might be too new, a potential knowledge gap. Thirdly, another cluster of risk management was identified as "knowledge support" which included training, education, extension services, and updates from the government. This suggests the primary role of government in supporting farmers with more training and extension services, as highlighted by Fielke and Bardsley [59]. The two last risk strategies "new technology adoption" and "cooperation with other farmers" were not associated with any risk sources.

"Technology risk" and "new technology adoption" did not load highly on the same factor. Farmers that claimed to experience changes in technology did not consider new technology instalment as a strategy to address that particular risk. Besides, farmers do not appear to adopt new technology as a response to risk. "Technology risk" was clustered with "crop and animal diversification", possibly signifying that farmers used technology to boost productivity [60] rather than to address inherent risk. This could indicate that technology adaptation could be related to a long-term planning rather than being reactive to a specific risk. "Cooperation with other farmers" was not associated with any specific agricultural risks, which may indicate farmers' interaction with other farmers for purposes such as networking and social events, rather than to tackle specific risks.

\subsection{Socio-Economic Factors Affecting Farmers' Risk Perceptions and Management of Risks}

Few studies have investigated the socioeconomic factors influencing farmers' risk perceptions. Perceptions of risk can differ between male and female farmers [61-63], as female farmers were more concerned about the critical roles of education and extension service in farming [64]. Education has been positively related to personal risk, farm business risk, and off-farm income [61,65-67]. Results show mixed findings between the age of farmers and risk perceptions. In South Africa, older farmers were more worried about the possible shortage of farm labour than younger farmers [61]. According to Borges and Machado [67], however, age did not significantly affect farmers' risk perceptions in Brazil.

Some studies reported that farmers who managed larger farms were primarily concerned with production risks $[64,68,69]$. The geographic location of farms had a substantial impact on farmers' risk perceptions $[2,70,71]$, for instance, Norwegian farmers in areas with convenient transport tended to pay more attention to production risk than other risks when compared to farmers at more remote locations [11]. 
Despite weather-related risk and biosecurity threats being frequently mentioned in the 197 studies, factors affecting farmers' perceptions on weather-related risks have been extensively investigated, but factors influencing farmers' biosecurity risk perception have been sparsely studied. Driven and motivated by the trend and impact of climate change on agriculture, weather-related risk has received enormous interest from researchers and farmers alike [72]. Fewer studies (21) focused on the socio-economic factors affecting farmers' risk management strategies. Education levels, farm size, and farmers' experience in farming were found to have a significant impact on how farmers perceive and adopt risk management strategies $[27,67,73]$.

As socio-economic factors play essential roles in risk perception and risk management strategies $[18,74]$, more theoretical and empirical work should be done to explore the potential factors affecting farmers' risk perception and risk management.

\subsection{Barriers to the Management of Agricultural Risks}

The results of this review reveal a range of barriers to managing agricultural risks. However, most research on barriers to managing agricultural risks has presented results from case studies in large agricultural enterprises in developed economies [75,76] and in small-scale agriculture in developing countries $[2,77]$.

A lack of institutional support from the government was identified as a significant barrier to managing agricultural risks in both developing and developed countries. For example, in Nigeria, Baruwa, Masuku, and Alimi [78] a lack of a lack of marketing training and support from the government for plantain farmers was identified. Similarly, Indian farmers aiming to adopt organic farming practices encountered institutional problems and a lack of support from the government in acquiring new methods to control pests and diseases and accessing new markets [79]. The need for better institutional support from developed countries has been confirmed [17].

Poor and smallholder farmers are particularly vulnerable to agricultural risks $[2,80]$ and have difficulty adopting new technologies and crop types due to inadequate technical knowledge, lack of funds, and limitations to their production technology [81]. Financial and technical support from reliable sources is often inadequate [29,78]. For instance, smallholder farmers in Ethiopia, Madagascar, and Pakistan have reported failure in accessing formal financial services $[29,58,64]$.

\section{Research Gaps, Implications and Limitations}

This review has revealed a number of research gaps. Firstly, there is an apparent discrepancy between the frequency that risks are mentioned by farmers and the volume of research on socio-economic factors that explain the perception of risks. For example, despite biosecurity being the second most cited risk, there is very little knowledge on the factors driving biosecurity risk perception. In addition, no studies identified in the review covered both developing countries and developed countries, highlighting the opportunity for studies that explore risk across large gradients of development. The paucity of studies on education was highlighted, which points out the need for available training and extension services for farmers. This is most likely because the studies were not published in refereed journals and the number of articles may increase by expanding this review to unpublished literature.

Moreover, there is a need to understand why there is a mismatch between farmers' perceived agricultural risk sources and risk management strategies. A better understanding of why management strategies that appear to be a suitable response to particular risks are not employed might highlight further barriers to agricultural risk management, which, if overcome, could enhance the productivity of agricultural systems. Finally, surprisingly few studies take a comprehensive view of the factors that determine farmers' risk perceptions (18\%) and their risk management strategies (11\%).

The clusters of risk sources described in this review could be used as a basis for further research exploring why risks cluster, why farmers perceive certain risks as more threatening than others, and how this clustering affects farmers' management strategies. Finally, addressing the knowledge gap 
on socio-economic contextual factors that influence farmers' risk perceptions and decisions about management strategies could enable government programs to better target farmers who are more likely to be amenable to particular programs.

While unlikely to have influenced the conclusions, there were some limitations to this study. Firstly, grey literature was not included, limiting the sample size and diversity. We have no reason to believe, however, that the grey literature would have differed markedly from peer review literature in terms of scope and subject matter. Secondly, the analysis in this review was conducted at the article level, so it did not include details that might have emerged from the raw data, including farmer-level data, across the reviewed studies. Research is therefore required to capture the full diversity of farmers' opinions and their perceptions of specific risk sources and risk management strategies.

\section{Conclusions}

Risks associated with agriculture are increasingly diverse, complex, and interconnected. Consequently, there is a pressing need to gain a greater understanding of the nexus of agricultural risks, how farmers respond to risk, factors affecting their perceptions and management of risk, and barriers hindering the way they manage risks to ensure stable livelihoods and global food security. Here, we have reviewed the literature within this intellectual space, shedding light on what is known and what still needs to be known. We also revealed some interesting anomalies and points of interest including the absence of studies across large developmental gradients, the small disproportionality volume of research on biosecurity risk management strategies and socioeconomic factors associated with biosecurity threats, the apparent mismatch between perceived risks and management responses, and the clustering of risks and risk management strategies. A better understanding of farmers' risk perceptions and risk management strategies, factors affecting their perceptions and management, and the barriers to their risk management could enable more collaborative solutions to managing future risks.

Supplementary Materials: The following are available online at http:/ /www.mdpi.com/2077-0472/9/1/10/s1. Table S1: List of 197 studies included in the review, Table S2: Spearman tests between market risks and risk management strategies, Table S3: Socio-economic factors affecting farmers' perception of agricultural risk sources $(n=35)$, Table S4: Socio-economic factors affecting farmers' perception of agricultural risk management strategies $(n=21)$, Table S5: Barriers affecting farmers' management of agricultural risk sources $(n=22)$.

Author Contributions: Conceptualization: T.T.D., K.Z., T.B.; Methodology: T.T.D.; Software: T.T.D.; Validation: T.T.D., K.Z., T.B., J.L.; Formal analysis: T.T.D.; Investigation: T.T.D.; Resources: T.T.D.; Data curation: T.T.D.; Writing-Original draft preparation: T.T.D.; Writing—Review and editing: T.T.D., K.Z., T.B., J.L.; Visualization: T.T.D.; Supervision: K.Z., T.B., J.L.; Project administration: T.T.D.

Funding: This research was funded by Plant Biosecurity Cooperative Research Centre Australia and Charles Darwin University, Australia.

Acknowledgments: This work has been supported by Plant Biosecurity Cooperative Research Centre Australia and Charles Darwin University, Australia. We thank Jeremy Garnett for his editing this manuscript.

Conflicts of Interest: None of the authors have any financial, personal or any other relationships that may lead to a potential conflict of interests.

\section{References}

1. Martin, S. Risk management strategies in New Zealand Agriculture and Horticulture. Rev. Mark. Agric. Econ. 1996, 64, 31-44.

2. Legesse, B.; Drake, L. Determinants of smallholder farmers' perceptions of risk in the Eastern Highlands of Ethiopia. J. Risk Res. 2005, 8, 383-416. [CrossRef]

3. Ullah, R.; Shivakoti, G.P.; Zulfiqar, F.; Kamran, M.A. Farm risks and uncertainties: Sources, impacts and management. Outlook Agric. 2016, 45, 199-205. [CrossRef]

4. Carvalho, F.P. Agriculture, pesticides, food security and food safety. Environ. Sci. Policy 2006, 9, 685-692. [CrossRef] 
5. Sulewski, P.; Kloczko-Gajewska, A. Farmers' risk perception, risk aversion and strategies to cope with production risk: An empirical study from Poland. Stud. Agric. Econ. 2014, 116, 140-147. [CrossRef]

6. Poulsen, M.N.; McNab, P.R.; Clayton, M.L.; Neff, R.A. A systematic review of urban agriculture and food security impacts in low-income countries. Food Policy 2015, 55, 131-146. [CrossRef]

7. Harwood, J.; Heifner, R.; Coble, K.; Perry, J.; Somwaru, A. Managing Risk in Farming: Concepts, Research, and Analysis; Department of Agriculture, Economic Research Service, Market and Trade Economics Division and Resource Economics Division: Washington, DC, USA, 1999.

8. Hardaker, J.B.; Lien, G.; Anderson, J.R.; Hurine, R. Coping with Risk in Agriculture: Applied Decision Analysis, 3rd ed.; CAB International Publishing Company: Wallingford, UK, 2015; p. 296.

9. Mankad, A. Psychological influences on biosecurity control and farmer decision-making. A review. Agron. Sustain. Dev. 2016, 36, 40. [CrossRef]

10. Meuwissen, M.P.M.; Huirne, R.B.M.; Hardaker, J.B. Risk and risk management: An empirical analysis of Dutch livestock farmers. Livest. Sci. 2001, 69, 43-53. [CrossRef]

11. Flaten, O.; Lien, G.; Koesling, M.; Vallec, P.S.; Ebbesvikb, M. Comparing risk perceptions and risk management in organic and conventional dairy farming: Empirical results from Norway. Livest. Prod. Sci. 2005, 95, 11-25. [CrossRef]

12. Bergfjord, O.J. Risk perception and risk management in Norwegian aquaculture. J. Risk Res. 2009, 12, 91-104. [CrossRef]

13. World Bank. Managing Agricultural Production Risks-Innovations in Developing Countries; Report No. 32727-GLB; World Bank: Washington, DC, USA, 2005.

14. Ahsan, D.A. Farmers' motivations, risk perceptions and risk management strategies in a developing economy: Bangladesh experience. J. Risk Res. 2011, 14, 325-349. [CrossRef]

15. Bergfjord, O.J. Farming and risk attitude. Emir. J. Food Agric. 2013, 25, 555-561. [CrossRef]

16. Knutson, C.L.; Haigh, T.; Hayes, M.J.; Widhalm, M.; Nothwehr, J.; Kleinschmidt, M.; Graf, L. Farmer perceptions of sustainable agriculture practices and drought risk reduction in Nebraska, USA. Renew. Agric. Food Syst. 2011, 26, 255-266. [CrossRef]

17. Woods, B.A.; Nielsen, H.Ø.; Pedersen, A.B.; Kristofersson, D. Farmers' perceptions of climate change and their likely responses in Danish agriculture. Land Use Policy 2017, 65, 109-120. [CrossRef]

18. Botterill, L.; Mazur, N. Risk and Risk Perception: A Literature Review: A Report for the Rural Industries Research and Development Corporation (RIRDC Publication No 04/043); Rural Industries Research and Development Corporation: Canberra, Australia, 2004.

19. OECD. Managing Risk in Agriculture: Policy Assessment and Design; OECD Publishing: Paris, France, 2011.

20. Menapace, L.; Colson, G.; Raffaelli, R. Risk aversion, subjective beliefs, and farmer risk management strategies. Am. J. Agric. Econ. 2013, 95, 384-389. [CrossRef]

21. Lewerin, S.S.; Österberg, J.; Alenius, S.; Elvander, M.; Fellström, C.; Tråvén, M.; Wallgren, P.; Karin, P.W.; Jacobson, M. Risk assessment as a tool for improving external biosecurity at farm level. BMC Vet. Res. 2015, 11. [CrossRef] [PubMed]

22. Tzouramani, I.; Alexopoulos, G.; Kostianis, G.; Kazakopoulos, L. Exploring risk management strategies for organic farmers: A Greek case study. Renew. Agric. Food Syst. 2013, 29, 167-175. [CrossRef]

23. Winsen, F.V.; Mey, Y.D.; Lauwers, L.; Passel, S.V.; Mark Vancauteren, M.; Wauters, E. Cognitive mapping: A method to elucidate and present farmers' risk perception. Agric. Syst. 2014, 122, 42-52. [CrossRef]

24. Saqib, S.E.; Ahmad, M.M.; Panezai, S.; Rana, I.A. An empirical assessment of farmers' risk attitudes in flood-prone areas of Pakistan. Int. J. Disaster Risk Reduct. 2016, 18, 107-114. [CrossRef]

25. Oo, T.A.; Van Huylenbroeck, G.; Speelman, S. Determining factors for the application of climate change adaptation strategies among farmers in Magwe District, dry zone region of Myanmar. Int. J. Clim. Chang. Strateg. Manag. 2017, 9, 36-55.

26. Ochieng, J.; Kirimi, L.; Makau, J. Adapting to climate variability and change in rural Kenya: Farmer perceptions, strategies and climate trends. Nat. Resour. Forum 2017, 41, 195-208. [CrossRef]

27. Lu, W.; Latif, A.; Ullah, R. Simultaneous adoption of contract farming and off-farm diversification for managing agricultural risks: The case of flue-cured Virginia tobacco in Pakistan. Nat. Hazards 2017, 86, 1347-1361. [CrossRef]

28. Bastakoti, R.C.; Gupta, J.; Babel, M.S.; van Dijk, M.P. Climate risks and adaptation strategies in the Lower Mekong River basin. Reg. Environ. Chang. 2013, 14, 207-219. [CrossRef] 
29. Harvey, C.A.; Rakotobe, Z.L.; Rao, N.S.; Dave, R.; Razafimahatratra, H.; Rabarijohn, R.H.; Rajaofara, H.; MacKinnon, J.L. Extreme vulnerability of smallholder farmers to agricultural risks and climate change in Madagascar. Philos. Trans. Royal Soc. B 2014, 369, 1-12. [CrossRef]

30. Visschers, V.H.; Backhans, A.; Collineau, L.; Iten, D.; Loesken, S.; Postma, M.; Belloc, C.; Dewulf, J.; Emanuelson, U.; Beilage, E.G.; et al. Perceptions of antimicrobial usage, antimicrobial resistance and policy measures to reduce antimicrobial usage in convenient samples of Belgian, French, German, Swedish and Swiss pig farmers. Prev. Vet. Med. 2015, 119. [CrossRef] [PubMed]

31. Moher, D.; Liberati, A.; Tetzlaff, J.; Altman, D.G. Preferred reporting items for systematic reviews and meta-analyses: The PRISMA statement. Br. Med. J. 2009, 339, 332-336. [CrossRef]

32. Musser, W.; Patrick, G. How Much Does Risk Really Matter to Farmers? A Comprehensive Assessment of the Role of Risk in U.S.; Just, R.E., Pope, R.D., Eds.; Kluwer Academic Publisher: Norwell, MA, USA, 2002.

33. Kahan, D. Managing Risks in Farming; FAO: Rome, Italy, 2013.

34. Traxler, G.; Falck-Zepeda, J.; Ortiz-Monasterio, R.J.I.; Sayre, K. Production risk and the evolution of varietal technology. Am. J. Agric. Econ. 1995, 77, 1-7. [CrossRef]

35. Sassenrath, G.F.; Heilman, P.; Luschei, E.; Bennet, G.L.; Fitzgerald, G.; Klesius, P.; Tracy, W.; Williford, J.R.; Zimba, P.V. Technology, complexity and change in agricultural production systems. Princ. Integr. Agric. Syst. 2008, 23, 285-295. [CrossRef]

36. Fraser, G. Biosecurity and food security-effective mechanism for public-private partnerships. Food Secur. 2015, 8, 83-87. [CrossRef]

37. Ju, H.; Velde, M.V.D.; Lin, E.; Xiong, W.; Li, Y. The impact of climate change on agricultural production systems in China. Clim. Chang. 2013, 120, 313-324. [CrossRef]

38. Anandhi, A.; Steiner, J.L.; Bailey, N. A system's approach to access the exposure of agricultural production to climate change and variability. Clim. Chang. 2016, 136, 647-659. [CrossRef]

39. Hay, J. Extreme weather and climate events, and farming risks. In Managing Weather and Climatic Risks in Agriculture; Sivakumar, M.V.K., Motha, R.P., Eds.; Springer: Berlin/Heidelberg, Germany, 2007.

40. Wood, J.M.; Tataryn, D.J.; Gorsuch, R.L. Effects of Under- and Overextraction on Principal Axis Factor Analysis with Varimax Rotation. Psychol. Methods 1996, 1, 354-365. [CrossRef]

41. Waage, J.K.; Mumford, J.D. Agricultural biosecurity. Philos. Trans. R. Soc. Lond. B Biol. Sci. 2008, 363, 863-876. [CrossRef] [PubMed]

42. Morera, M.C.; Monaghan, P.F.; Tovar-Aguilar, J.A.; Galindo-Gonzalez, S.; Roka, F.M.; Asuaje, C. Improving health and safety conditions in agriculture through professional training in Florida farm labor supervisors. J. Agromed. 2014, 19, 117-122. [CrossRef] [PubMed]

43. Morton, J.F. The impact of climate change on smallholder and subsistence agriculture. Proc. Natl. Acad. Sci. USA 2007, 104. [CrossRef] [PubMed]

44. Müller, C.; Cramer, W.; Hare, W.L.; Lotze-Campen, H.; Kates, R.W. Climate change risks for African agriculture. Proc. Natl. Acad. Sci. USA 2011, 108, 4313-4315. [CrossRef]

45. Girdžiūte, L. Risks in agriculture and Opportunities of their integrated Evaluation. Procedia Soc. Behav. Sci. 2012, 62, 783-790. [CrossRef]

46. Lin, B.B. Resilience in agriculture through crop diversification: Adaptive management for environmental change. BioScience 2011, 61, 183-193. [CrossRef]

47. Jin, J.; Gao, Y.; Wang, X.; Nam, P.K. Farmers' risk preferences and their climate change adaptation strategies in the Yongqiao District, China. Land Use Policy 2015, 47, 365-372.

48. Gillespie, J.; Mishra, A. Off-farm employment and reasons for entering farming as determinants of production enterprise selection in US agriculture. Aust. J. Agric. Resour. Econ. 2011, 55, 411-428. [CrossRef]

49. Ruiz, J.; Bielza, M.; Garrido, A.; Iglesias, A. Dealing with draught in irrigated agriculture through insurance schemes: An application to an irrigation district in Southern Spain. Span. J. Agric. Res. 2015, 13. [CrossRef]

50. Aldy, J.E.; Hrubovcak, J.; Vasavada, U. The role of technology in sustaining agriculture and the environment. Ecol. Econ. 1998, 26, 81-96. [CrossRef]

51. Atreya, K. Farmers' willingness to pay for community integrated pest management training in Nepal. Agric. Hum. Values 2007, 24, 399-409. [CrossRef]

52. Gautam, S.; Schreinemachers, P.; Uddin, N.; Srinivasan, R. Impact of training vegetable farmers in Bangladesh in integrated pest management (IPM). Crop Protect. 2017, 102, 161-169. [CrossRef] 
53. Siroco, M.; Maksat, A.; Peter, T. Vocational Education and Training for Woman Farmers in Kyrgyzstan: A Case Study of an Innovative Education Programme. J. Vocat. Educ. Train. 2006, 58, 455-469.

54. Alamerie, K.; Ketema, M.; Gelaw, F. Risks in vegetables production from the perspective of smallholder farmers: The case of Kombolcha Woreda, Oromia region, Ethiopia. Agric. For. Fish. 2014, 3, 1-5.

55. Patrick, G.F.; Ullerich, S. Information sources and risk attitudes of large-scale farmers, farm managers, and agricultural bankers. Agribusiness 1996, 12, 461-471. [CrossRef]

56. Martin, S.; McLeay, F. The diversity of farmers' risk management strategies in a deregulated New Zealand environment. J. Agric. Econ. 1998, 49, 218-233. [CrossRef]

57. Palinkas, P.; Szekely, C.S. Farmer's Risk Perception and Risk Management Practices in International Comparison. Available online: http:/ / purl.umn.edu/ 47554 (accessed on 22 December 2017).

58. Gebreegziabher, K.; Tadesse, T. Risk perception and management in smallholder dairy farming in Tigray, Northern Ethiopia. J. Risk Res. 2014, 3, 367-381. [CrossRef]

59. Fielke, S.J.; Bardsley, D.K. The importance of farmer education in South Australia. Land Use Policy 2014, 39, 301-312. [CrossRef]

60. Chang, S.C.; Tsai, C.H. The adoption of new technology by the farmers in Taiwan. Appl. Econ. 2015, 47, 3817-3824. [CrossRef]

61. Kisaka-Lwayo, M.; Obi, A. Risk perceptions and management strategies by smallholder farmers in KwaZulu-Natal Province, South Africa. Int. J. Agric. Manag. 2012, 1, $28-39$.

62. Lasco, R.D.; Espaldon, M.L.O.; Habito, C.M.D. Smallholder farmers' perceptions of climate change and the roles of trees and agroforestry in climate risk adaptation: Evidence from Bohol, Philippines. Agrofor. Syst. 2015, 90, 521-540. [CrossRef]

63. Kiama, T.N.; Lindahl, J.F.; Sirma, A.J.; Senerwa, D.M.; Waithanji, E.M.; Ochungo, P.A.; Poole, E.J.; Kang, E.K.; Grace, D. Kenya dairy farmer perception of moulds and mycotoxins and implications for exposures to aflatoxins: A gender analysis. Afr. J. Food Agric. Nutr. Dev. 2016, 16, 11106-11125. [CrossRef]

64. Ullah, R.; Shivakoti, G.P.; Ali, G. Factors effecting farmers' risk attitude and risk perceptions: The case of Khyber Pakhtunkhwa, Pakistan. Int. J. Disaster Risk Reduct. 2015, 13, 151-157. [CrossRef]

65. Stockil, R.C.; Ortmann, G.F. Perceptions of risk among commercial farmers in Kwazulu-natal in a changing economic environment. Agrekon 1997, 36, 139-159. [CrossRef]

66. Elkin, P.D. Perceptions of Risk, Stressors, and Locus of Control Influence Intentions to Practice Safety Behaviors in Agriculture. J. Agromed. 2007, 12, 7-25. [CrossRef]

67. Borges, J.A.R.; Machado, J.A.D. Risks and Risk Management Mechanisms: An Analysis of the Perceptions of Producers of Agricultural Commodities. Interdiscip. J. Res. Bus. 2012, 2, 27-39.

68. Boggess, W.G.; Anaman, K.A.; Hanson, G.D. Importance, causes, and management responses to farm risks: Evidence from Florida and Alabama. South. J. Agric. Econ. 1985, 17, 105-116. [CrossRef]

69. Nmadu, J.N.; Eze, G.P.; Jirgi, A.J. Determinants of risk status of small scale farmers in Niger State, Nigeria. Br. J. Econ. Manag. Trade 2012, 2, 92-108. [CrossRef]

70. Rios-Gonzalez, A.; Jansen, K.; Sanchez-Perez, H.J. Pesticide risk perceptions and the differences between farmers and extensionists: Towards a knowledge-in-context model. Environ. Res. 2013, 124, 43-53. [CrossRef] [PubMed]

71. Kabir, M.I.; Rahman, M.B.; Smith, W.; Lusha, M.A.; Azim, S.; Milton, A.H. Knowledge and perception about climate change and human health: Findings from a baseline survey among vulnerable communities in Bangladesh. BMC Public Health 2016, 16, 266. [CrossRef] [PubMed]

72. Wheeler, T.; Joachim von Braun, J.V. Climate change impacts on global food security. Science 2013, 341, 508-513. [CrossRef] [PubMed]

73. Hall, D.C.; Knight, T.O.; Coble, K.H.; Baquet, A.E.; Patrick, G.F. Analysis of beef producers' risk management perceptions and desire for further risk management education. Rev. Agric. Econ. 2003, 25, 430-448. [CrossRef]

74. Sjöberg, L. Factors in risk perception. Risk Anal. 2000, 20, 1-12. [CrossRef]

75. Toma, L.; Stott, A.W.; Feffernan, C.; Ringrose, S.; Gunn, G.J. Determinants of biosecurity behaviour of British cattle and sheep farmers-A behavioral economics analysis. Prev. Vet. Med. 2013, 108, 321-333. [CrossRef] [PubMed]

76. Ilbery, B.; Maye, D.; Ingram, J.; Little, R. Risk perception, crop protection and plant disease in the UK wheat sector. Geoforum 2013, 50, 129-137. [CrossRef] 
77. Mardero, S.; Schmook, B.; Radel, C.; Christman, Z.; Lawrence, D.; Millones, M.; Nickl, E.; Rogan, J.; Schneider, L. Smallholders' adaptations to droughts and climatic variability in southeastern Mexico. Environ. Hazards 2015, 14, 271-288. [CrossRef]

78. Baruwa, O.I.; Masuku, M.B.; Alimi, T. Managing farm risk: Issues and strategies in plantain production in Osun State, Nigeria. Int. J. Hortic. 2015, 5, 1-7. [CrossRef]

79. Panneerselvam, P.; Halberg, N.; Vaarst, M.; Hermansen, J.E. Indian farmers' experience with and perceptions of organic farming. Renew. Agric. Food Syst. 2011, 27, 157-169. [CrossRef]

80. Mannon, S.E. Risk takers, risk makers: Small farmers and non-traditional agro-exports in Kenya and Costa Rica. Hum. Organ. 2005, 64, 16-27. [CrossRef]

81. Awan, M.I.; Oort, P.J.V.; Ahmad, R.; Bastiaans, L.; Meinke, H. Farmers' views on the future prospects of aerobic rice culture in Pakistan. Land Use Policy 2015, 42, 517-526. [CrossRef]

(C) 2019 by the authors. Licensee MDPI, Basel, Switzerland. This article is an open access article distributed under the terms and conditions of the Creative Commons Attribution (CC BY) license (http://creativecommons.org/licenses/by/4.0/). 